\title{
An investigation of Teratak Buluh sand as a foam mortar aggregate material
}

\author{
Elsa Eka Putri $^{1 *}$, Doni Rinaldi Basri ${ }^{2,3}$, and Bayu Martanto Adji ${ }^{2}$ \\ ${ }^{1}$ Civil Engineering Department, Faculty of Engineering, University of Andalas, 25163, Padang, Indonesia \\ ${ }^{2}$ Civil Engineering Department, Faculty of Engineering, University of Abdurrab, 28292, Pekanbaru, Indonesia \\ ${ }^{3}$ Doctoral Student, Civil Engineering Department, University of Andalas, 25163, Padang, Indonesia
}

\begin{abstract}
Riau Province has the largest peat soil on Sumatra island. Peat soil has a low bearing capacity and very deep hard soil depth, even in some places up to 16 meters depth. This condition makes the construction of roads on peat soils will experience significant and unavoidable degradation and damage if no special handling is conducted. One of the efforts to overcome the situation in road construction is the use of foam mortar which has been developed by the Road and Bridge Research Centre (PUSJATAN) in 2013 which discovered the Foam Mortar Light Pile technology. This foam mortar is a cement mixture that has a lower density than water. This study conducted further research on finding the ratio of Cement vs. Sand in foam mortar which has a specific gravity smaller than water. The sand comes from Teratak Buluh Village, Kampar Regency, Riau Province and Cement (PCC) comes from Padang City, West Sumatra Province. The cement and sand ratio was varied; $1 \mathrm{C}: 0.7 \mathrm{~S}, 1 \mathrm{C}: 0.8 \mathrm{~S}, 1 \mathrm{C}: 0.9 \mathrm{~S}, 1 \mathrm{C}: 1.0 \mathrm{~S}, 1 \mathrm{C}: 1.1 \mathrm{~S}$ and $1 \mathrm{C}: 1.2 \mathrm{~S}$. Cylindrical samples with a diameter of 10 $\mathrm{cm}$ and a height of $20 \mathrm{~cm}$ were subjected to a compression test using a modified CBR tool at the 7 day curing time. From the test results, samples at a ratio of $1 \mathrm{C}: 0.7 \mathrm{~S}$ and $1 \mathrm{C}: 0.8 \mathrm{~S}$ can float in water, with a density of 0.77 tonne $/ \mathrm{m}^{3}$ and compressive strength of $901.20 \mathrm{kPa}$ and a density of 0.83 tonne $/ \mathrm{m}^{3}$ with a compressive strength of $971.35 \mathrm{kPa}$ respectively.
\end{abstract}

\section{Introduction}

Riau Province has the widest peat soil type on Sumatra Island, 4,044 million ha $(56.1 \%$ of the total area of Sumatra island or $45 \%$ of the Riau mainland area. This peat soil has a low bearing capacity and has a very deep hard soil depth, even in some places it has a depth of up to 16 meters.

Peat soil consists of organic fragments, derived from vegetation that has changed and is chemically fossilized, the accumulation of organic matter forms peat soil [1].

Peat soil has a low bearing capacity; thus, it needs the effort to strengthen the soil to avoid excessive settlement and permanent deformation.

Road and Bridge Research Centre (PUSJATAN) in 2013 developed a new technology called Foam Mortar Lightweight Technology [2]. This foam mortar has a specific gravity that is smaller than water and can carry a minimum load of $800 \mathrm{kPa}$ so that it can be used as a substitution for embankment soil on road pavements in low-bearing capacity soil.

The main purpose of this research is to determine the cement: a sand ratio that produces foam mortar under the requirements as per PUSJATAN 2013, then study the effect of the ratio of cement vs. sand on the density and compressive strength using local material, i.e. the sand comes from Teratak Buluh Village, Kampar Regency, Riau Province, and cement type is Portland Cement Concrete (PCC).

\section{Literature Review}

Foam mortar consists of mortar and foam agent, the mortar consists of cement, sand, water, while foam consists of foam agent and water [3].

In the direct loading test in the field, it was seen that the design of the embankment with foam mortar material resulted in lesser soil compression value than the embankment with sandstone soil material, due to the foam mortar material being lighter and more stable [4].

Research on the use of foam agents in the manufacture of lightweight concrete bricks has been carried out by adding a foaming agent in the concrete mixture to produce the lightweight concrete [5]. Sample was tested using a cube mould, with the composition of cement vs. sand of $1: 0.5 ; 1: 0.7$ and $1: 0.9$ produce a compressive strength of $17,422 \mathrm{~kg} / \mathrm{cm} 2 ; 14,756 \mathrm{~kg} / \mathrm{cm} 2$ and $9,778 \mathrm{~kg} / \mathrm{cm} 2$ with a weight of $2.510 \mathrm{~kg}, 2.748 \mathrm{~kg}$ and $2.808 \mathrm{~kg}$ respectively [5].

\footnotetext{
* Corresponding author: elsaeka@eng.unand.ac.id
} 
Moreover, the investigation on foam concrete has also been carried out using a mixture ratio of cement, sand, and water 1:1.5: 0.5 [6]. In this study, the foam agents were added starting from $28 \%, 45 \%, 62 \%$, and $78 \%$. With the addition of $28 \%$ foam agent, the density value is between $1770 \mathrm{~kg} / \mathrm{m}$, while for $78 \%$ addition the density value becomes $500 \mathrm{~kg} / \mathrm{m}^{3}$ [6].

Using the alternative type of construction CSS-Mortar Foam can reduce the cost of flyover construction by $44.7 \%$ when compared to the PCI-Girder construction type [7].

The effect of polycarboxylate Superplasticizer (SP) content on foam concrete properties has also been investigated [8]. The results of the study show that the water-cement and Superplasticizer (SP) factors have a significant influence on the performance of foam concrete. The use of $1.35 \%$ SP improves the mechanical and transport properties of foam concrete [8].

The results of the study with the addition of ground calcium carbonate (GCC) increased the compressive strength and thermal conductivity due to the effect of filling and the addition of glass fibre (GF) contributed to the flexural strength of the concrete [9].

Meanwhile, investigation of the effect of the concentration of foaming agents and their microwave and ultrasonic treatments concerning foam stability, bulk density, microstructure, and compressive strength produced has been examined [10]. The reduction in pore size contributed to the increase in compressive strength determined in the samples prepared with lower microwave concentrations and ultrasonically treated foaming agents. The lower concentration of the foaming agent itself also has a positive effect on the stability of the foam. However, the influence is not so prominent [10].

Moreover, an experimental study of the raw material properties, possible changes, and new formations in the inner layer of porous materials provide an improved construction and operational properties of autoclaved foam concrete [11]

In this study, the ratio of cement vs. sand was varied by $1 \mathrm{C}: 0.7 \mathrm{~S}, 1 \mathrm{C}: 0.8 \mathrm{~S}, 1 \mathrm{C}: 0.9 \mathrm{~S}, 1 \mathrm{C}: 1.0 \mathrm{~S}, 1 \mathrm{C}: 1.1 \mathrm{~S}$ and $1 \mathrm{C}: 1.2 \mathrm{~S}$. This variation was chosen to find the ratio of cement vs. sand mixture that produced the lightweight concrete which had a density of less than 1 , shown by the floating of the concrete sample in the water.

\section{Materials and Methods}

\subsection{Materials}

Foam concrete can be categorized as mortar because its constituent materials consist of cement, sand, water, and foam. The foam was obtained from mixing foam agent and water in a ratio of 1:20. Foam mortar is categorized as mortar because it does not contain coarse aggregate. Meanwhile, the air trapped in the foam mortar caused by the chemical reaction was expected to reduce the specific gravity of the mortar.

The mixture of materials consists of cement, sand, and water. All materials are mixed using a laboratory mixer, with variations in the material composition according to the mix plan to obtain the desired lightweight material specifications. The mixture must be free from lumps. The sand used passed No. 10 sieve size and was retained by the No. 200 sieve size [3].

The weight of each material to form $1 \mathrm{~m}^{3}$ of mortar mixture has been calculated and the result is presented as shown in Table 1.

Table 1. Weight of Material to produce $1 \mathrm{~m}^{3}$ Foam Mortar

\begin{tabular}{|c|c|c|c|c|c|c|}
\hline & \multicolumn{7}{|c|}{ Cement: Sand Ratio } \\
\cline { 2 - 7 } Materials & $\begin{array}{c}\mathbf{1 C}: \\
\mathbf{0 . 7}\end{array}$ & $\begin{array}{c}\mathbf{1 C}: \\
\mathbf{0 . 8 S}\end{array}$ & $\mathbf{1 C : 0 . 9 S}$ & $\begin{array}{c}\mathbf{1 C}: \\
\mathbf{1 . 0 S}\end{array}$ & $\begin{array}{c}\mathbf{1 C}: \\
\mathbf{1 . 1 S}\end{array}$ & $\begin{array}{c}\mathbf{1 C}: \\
\mathbf{1 . 2 S}\end{array}$ \\
\hline $\begin{array}{c}\text { Cement } \\
(\mathrm{kg})\end{array}$ & 250 & 250 & 250 & 250 & 250 & 250 \\
\hline $\begin{array}{c}\text { Sand } \\
(\mathrm{kg})\end{array}$ & 174.9 & 200.12 & 224.89 & 250.05 & 275.02 & 299.98 \\
\hline $\begin{array}{c}\text { Water } \\
(\mathrm{kg})\end{array}$ & 125 & 125 & 125 & 125 & 125 & 125 \\
\hline $\begin{array}{c}\text { Foam } \\
(\mathrm{kg})\end{array}$ & 47.24 & 46.62 & 45.99 & 45.34 & 44.71 & 44.07 \\
\hline
\end{tabular}

Table 1 is the weight of the material of Foam Mortar for $1 \mathrm{~m}^{3}$. Meanwhile, Table 2 is the weight of all materials for 3 samples at each composition.

Table 2. Weight of Material for Foam Mortar Composition Materials for 3 samples per mixture

\begin{tabular}{|c|l|l|l|l|l|l|}
\hline \multirow{2}{*}{ Materials } & \multicolumn{6}{|c|}{ Cement: Sand } \\
\cline { 2 - 7 } & $\begin{array}{l}\text { 1C: } \\
\text { 0.7S }\end{array}$ & $\begin{array}{l}\text { 1C: } \\
\mathbf{0 . 8 S}\end{array}$ & $\begin{array}{l}\text { 1C: } \\
\text { 0.9S }\end{array}$ & $\begin{array}{l}\text { 1C: } \\
\text { 1.0S }\end{array}$ & $\begin{array}{l}\text { 1C: } \\
\mathbf{1 . 1 S}\end{array}$ & $\begin{array}{l}\text { 1C: } \\
\mathbf{1 . 2 S}\end{array}$ \\
\hline Cement $(\mathrm{kg})$ & 2.36 & 2.36 & 2.36 & 2.36 & 2.36 & 2.36 \\
\hline Sand (kg) & 1.65 & 1.89 & 2.12 & 2.36 & 2.59 & 2.83 \\
\hline Water (kg) & 1.18 & 1.18 & 1.18 & 1.18 & 1.18 & 1.18 \\
\hline Foam (kg) & 0.45 & 0.44 & 0.43 & 0.43 & 0.42 & 0.42 \\
\hline
\end{tabular}

As can be seen in Table 1 and Table 2, the weight of the water and cement for all samples are the same. Moreover, the weight of the sand was varied according to the cement vs. ratio predetermined [3].

\subsection{Methods}

The weight of each foam mortar is determined based on the Circular Letter of the Minister of Public Works and People's Housing (SE Minister of PUPR) No. 44 (2015), concerning the design guidelines for a mixture of lightweight materials with foam mortar for road construction [3].

\subsubsection{Volume Weight}

The volume weight analysis was carried out by dividing the sample weight (tonne) by the sample volume $\left(\mathrm{m}^{3}\right)$. 
The density was determined to find out the sample which has a density less than the water density, thus it can be used as lightweight material to replace the embankment as per the Road and Bridge Research Centre (PUSJATAN) [2].

Volume Weight $=\frac{\text { Sample Weight }(\text { tonne })}{\text { Sample Volume }\left(m^{3}\right)}$

(1)

The volume weight is the weight per unit volume of oven-dried soil, which is usually expressed as grams $/ \mathrm{cm}^{3}$ [12]

\subsubsection{Foam Production}

Mortars density was evaluated according to SE No:44/SE/M/2015 [3]. Foaming materials are liquid foam (foam agent) and water. To make foam, the foam liquid and water are mixed using a foam generator and a compressor (Fig. 1).

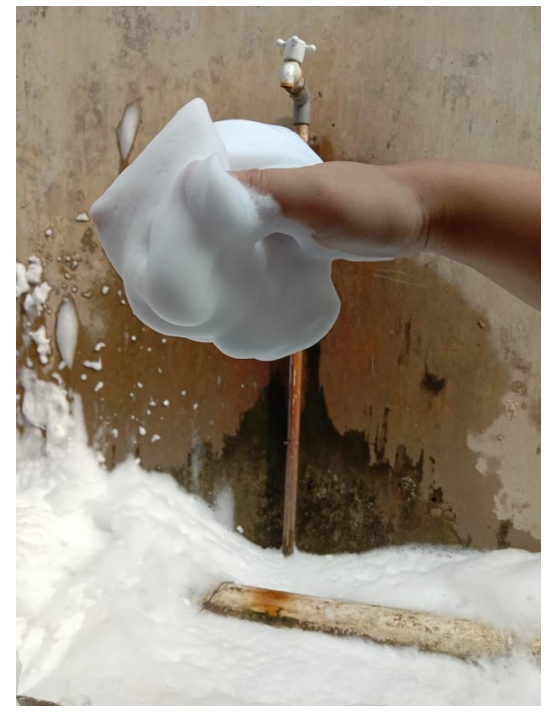

Fig. 1. Foam production

Samples were prepared in-cylinder mould with a diameter of $10 \mathrm{~cm}$ and a height of $20 \mathrm{~cm}$ as shown in Fig. 2.

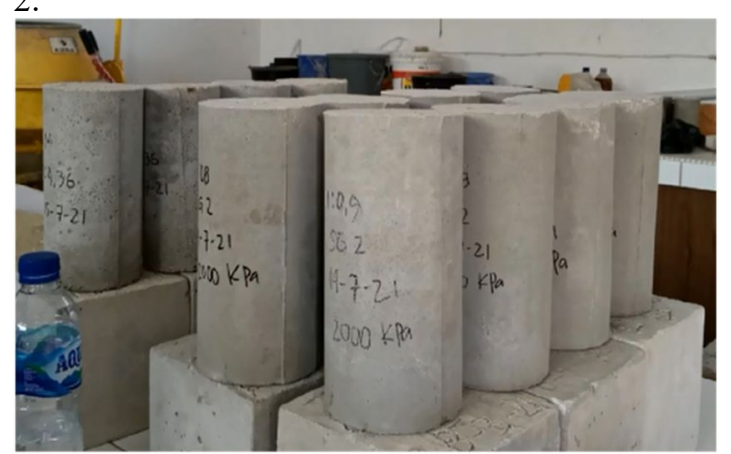

Fig. 2. Cylinder Sample

\subsubsection{Flow Test}

Foam is mixed with mortar and stirred until homogeneous. A flow test was conducted based on
ASTM C230-08 (2008) [5] was performed to check the workability and consistency.

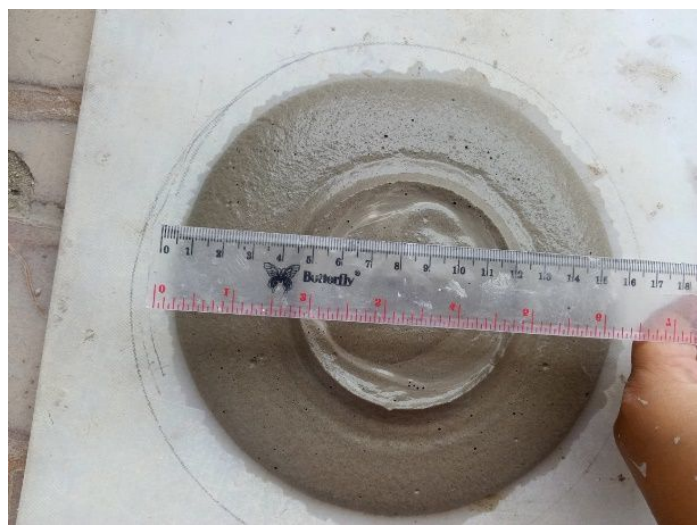

Fig. 3. Flow Test

The mortar sample was placed on a flow table and dropped 25 times within 15 seconds. After being dropped 25 times, the cone is lifted and the mortar is spread out on the flow table. The diameters for four angles of the spread mortar were measured and recorded.

Fig 3 is the measurement of the spreading mortar. The flow value is the diameter of the mortar that flows after the ring flow is removed. The flow value must be $18 \mathrm{~cm}$ $\pm 2 \mathrm{~cm}$ following the provisions of the SE Minister of PUPR No. 44 of 2015 [3,13].

Moreover, Fig. 4 is the cylindrical sample, which has been removed from the mould, then treated by wrapping the sample for 5 days. This is done to prevent water loss during the hardening process. So, there is no hydration due to the reaction of cement and water.

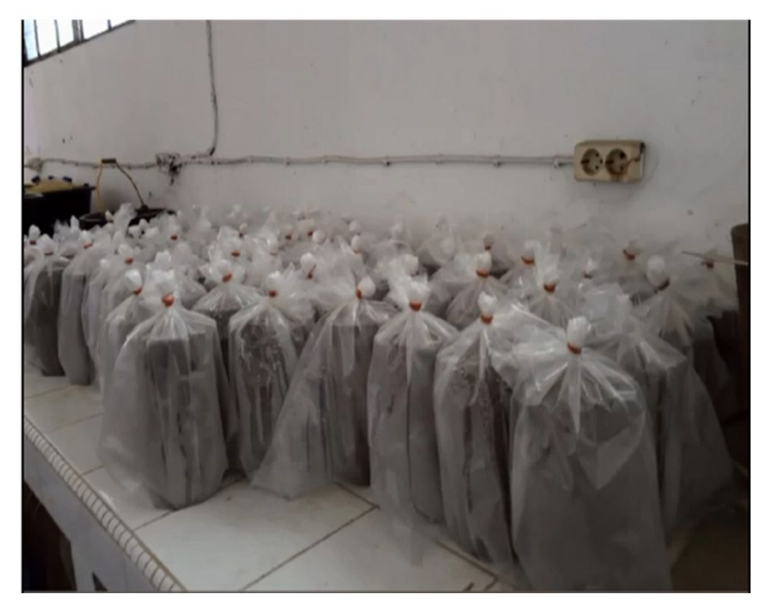

Fig. 4. Curing / Sample Maintenance

After curing for 5 days, the samples were removed and weighed. Samples were tested at the 7 days curing on a modified CBR test instrument as shown in Fig. 4. 


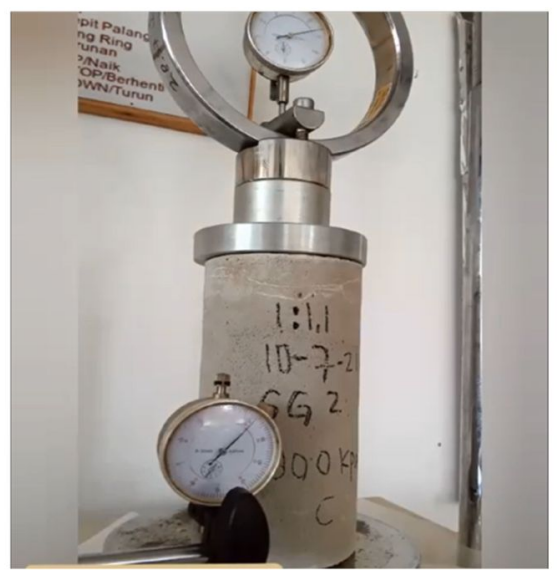

Fig. 4. Modified CBR Equipment

\subsubsection{Compressive Strength Test}

A compressive strength test is done to see the strength of the sample that has been made. Whether the strength can reach $800 \mathrm{kPa}$ according to the specified conditions [14].

This test was carried out with a modified CBR tool following the standards recommended by PUSJATAN. The compressive strength test with a modified CBR tool, as can be seen in Fig. 5 .

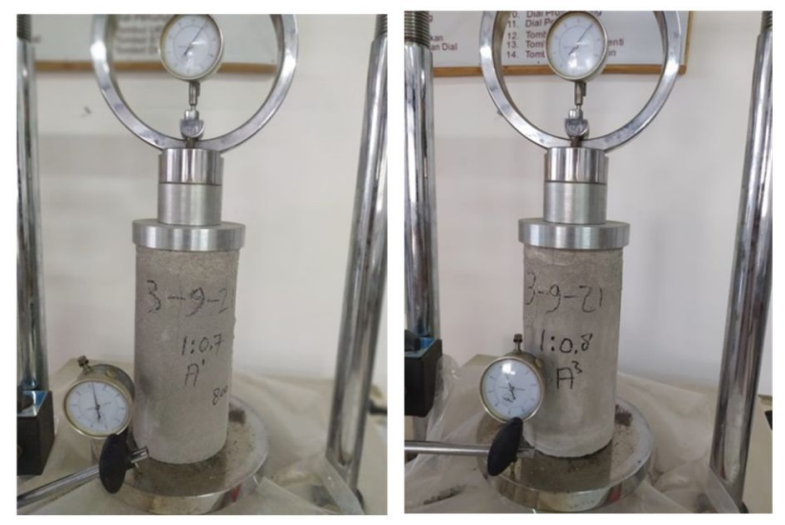

Fig. 5. Compressive test of sample 1C:0.7S \& 1C:0.8S

Fig. 5 shows the sample with cement vs. ratio. sand at the time of testing.

Compressive strength was determined by dividing the maximum load (Newton) by the area of the sample base $\left(\mathrm{mm}^{2}\right)$. Compressive Strength Analysis was carried out to determine the ability of the foam mortar to withstand compressive loads. The compressive strength of this foam mortar must be equal to or greater than the compressive strength of the embankment soil $(>800 \mathrm{kPa})$. Equation 2 is based on SNI 1974:2011, i.e. determination of compression strength of concrete cylinder [14,15].

$$
\text { Compression Strength }=\frac{\text { Load }(\text { Newton })}{\text { Area }\left(\mathrm{mm}^{2}\right)}
$$

\section{Results}

The results for the 7 days curing at various cement vs. sand ratios have been presented in Table 3. 2 main parameters have been investigated to find the suitable lightweight foam mortar to be applied at low-bearing peat soil i.e. unit weight and compressive strength.

Table 3. Unit weight and Strength for all samples

\begin{tabular}{|c|c|c|c|}
\hline \multirow{2}{*}{ Mixture } & \multirow{2}{*}{ Sample Name } & Unit weight & Strength \\
\hline & & tonne $/ \mathbf{m}^{3}$ & $\mathbf{k P a}$ \\
\hline \multirow{3}{*}{$1 \mathrm{C}: 0.7 \mathrm{~S}$} & A1 & 0.771 & 760.89 \\
\hline & A2 & 0.761 & 971.35 \\
\hline & A3 & 0.771 & 971.35 \\
\hline \multicolumn{2}{|c|}{ Average } & 0.768 & 901.198 \\
\hline \multirow{3}{*}{$1 \mathrm{C}: 0.8 \mathrm{~S}$} & A1 & 0.822 & 955.16 \\
\hline & A2 & 0.847 & $1,084.68$ \\
\hline & A3 & 0.822 & 874.22 \\
\hline \multicolumn{2}{|c|}{ Average } & 0.83 & 971.351 \\
\hline \multirow{3}{*}{$1 \mathrm{C}: 0.9 \mathrm{~S}$} & A1 & 0.99 & $1,505.59$ \\
\hline & A2 & 1.01 & $1,667.49$ \\
\hline & A3 & 0.99 & $1,376.08$ \\
\hline \multicolumn{2}{|c|}{ Average } & 0.997 & $1,516.39$ \\
\hline \multirow{3}{*}{$1 \mathrm{C}: 1 \mathrm{~S}$} & A1 & 0.959 & $1,036.11$ \\
\hline & A2 & 0.949 & $1,117.05$ \\
\hline & A3 & 0.98 & $1,214.19$ \\
\hline \multicolumn{2}{|c|}{ Average } & 0.962 & $1,122.45$ \\
\hline \multirow{3}{*}{$1 \mathrm{C}: 1.1 \mathrm{~S}$} & A1 & 0.93 & $1,181.81$ \\
\hline & A2 & 0.949 & 971.35 \\
\hline & A3 & 1.099 & $1,376.08$ \\
\hline \multicolumn{2}{|c|}{ Average } & 0.993 & $1,176.41$ \\
\hline \multirow{3}{*}{$1 \mathrm{C}: 1.2 \mathrm{~S}$} & A1 & 1.08 & $1,311.32$ \\
\hline & A2 & 1.019 & $1,084.68$ \\
\hline & A3 & 1.041 & $1,635.11$ \\
\hline \multicolumn{2}{|c|}{ Average } & 1.047 & $1,343.70$ \\
\hline
\end{tabular}

As can be seen from Table 3, as the amount of sand in the mixture increases the volume weight of the sample also increases. Only two ratios cement vs sand that satisfy the lightweight concrete criteria specified in SE 2015, i.e. $1 \mathrm{C}: 0.7 \mathrm{~S}$ and $1 \mathrm{C}: 0.8 \mathrm{~S}$. The $1 \mathrm{C}: 0.9 \mathrm{~S}$ or more having a density of more than 1 , means the sample cannot be float when immersed in water.

Moreover, all the compressive strength values of the cement vs. sand ratio have fulfilled the required in SE 2015 , with a minimum value of compressive strength of $800 \mathrm{kPa}$. 
Meanwhile, the average value of the Unit Weight, as well as compressive strength, were presented in Fig. 4 and 5.

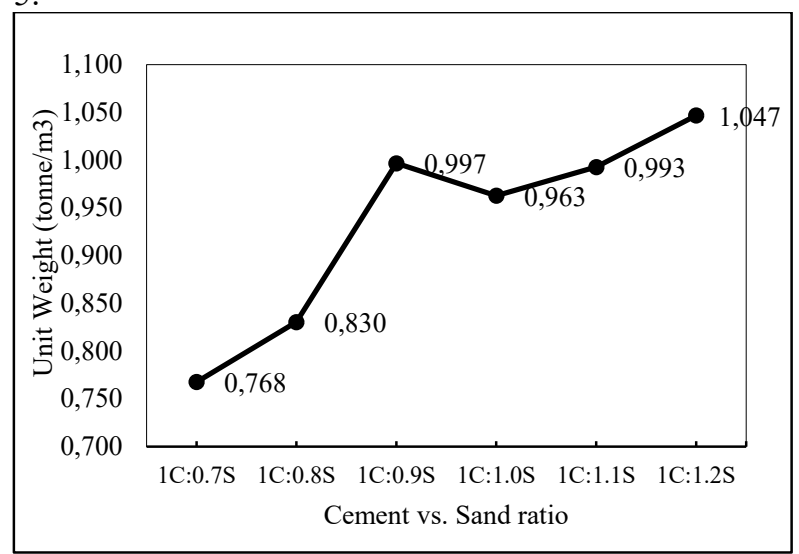

Fig. 6. Average Unit weight of sample for all various cement vs. sand

Fig. 6 shows an approximate linear transform, in which, unit weight increased with the increasing amount of sand in the mortar. It was noticeable which samples have unit weight lower than 1 .

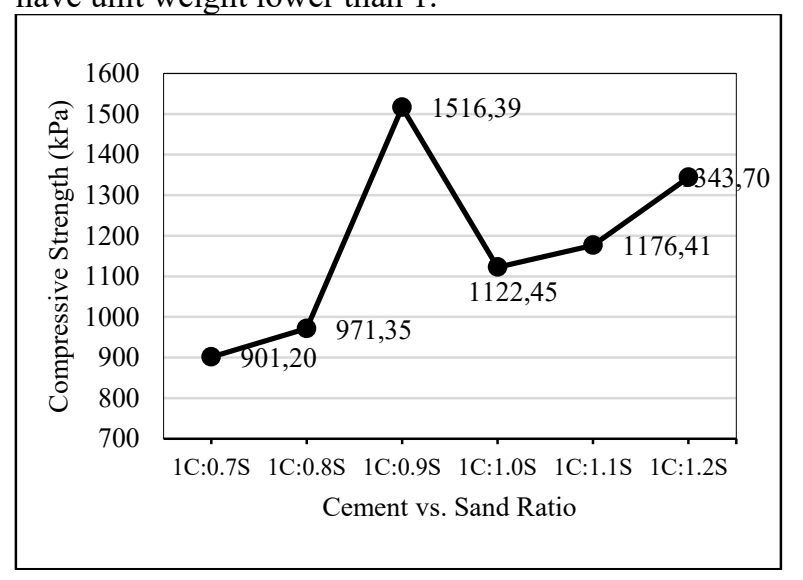

Fig. 7. Compressive Strength value cement vs. sand

As shown in Fig. 7, It shows an approximate linear regression, in which, compressive strength was increased when the sand level was increased.

It was noticeable that compressive strength in the $1 \mathrm{C}: 0.9 \mathrm{~S}$ ratio was high as well as its unit weight (Fig. 6). It seems that the higher the unit weight the higher the compressive strength.

Furthermore, as can be seen in Fig. 6, almost all samples have unit weight values below 1, only the highest sand ratio has unit weight values more than 1 .

Meanwhile, the compressive strength of all samples meets the requirements, which is greater than $800 \mathrm{kPa}$.

Hence, for the selection of which samples meet the requirements, the samples were directly immersed to see which cement vs. the sand ratio perfectly floats. Thus, it was found that $1 \mathrm{C}: 0.7 \mathrm{~S}$ and $1 \mathrm{C}: 0.8 \mathrm{~S}$ float perfectly, as shown in Fig. 8.

By choosing this ratio as the foundation layer, it is expected that the layer will not overburden the subgrade so that there will be no excessive settlement due to the load it carries.

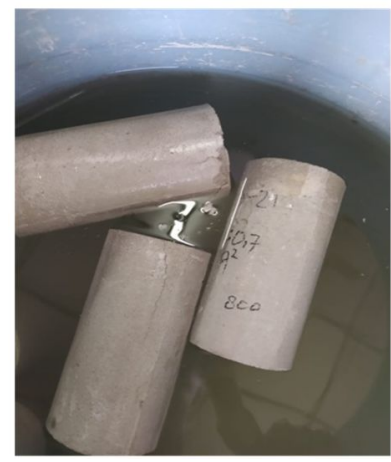

(a)

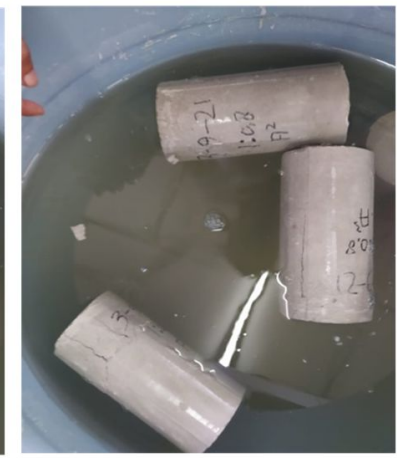

(b)
Fig. 8. Floating samples in water with cement vs. sand (a) $1: 0.7$ (b) $1: 0.8$

\section{Conclusions}

Based on the investigation, it can be concluded that

1. The use of sand from teratak buluh, in Riau province, as a material for foam mortar, has a high compressive strength value, where the values for all cement vs. sand ratios are above $800 \mathrm{kPa}$.

2. The composition that is suitable as a lightweight foundation layer for low-bearing peat soil, is a mixture that produces a unit weight value lower than 1, namely $1 \mathrm{C}: 0.7 \mathrm{~S}$ and $1 \mathrm{C}: 0.8 \mathrm{~S}$ which floats perfectly.

3. The selected ratio $1 \mathrm{C}: 0.7 \mathrm{~S}$ and $1 \mathrm{C}: 0.8 \mathrm{~S}$ has a high compressive value, more than $800 \mathrm{kPa}$.

The authors wish to acknowledge the Faculty of Engineering, the University of Andalas for a supported grant throughout our research.

\section{References}

1. S. R. N. Panjaitan, "A Study on the Value of Shear Strength in Muara Batang Toru Peat, North Sumatra After Experiencing Initial Compression (Kajian terhadap nilai kuat geser tanah gambut muara Batang Toru Sumatera Utara setelah mengalami pemampatan awal)," J. Ranc. Sipil, 2, no. 1, 2013.

2. S. Wicaksono and M. Iqbal, "Effectiveness Of Foamed Mortar Light Weight Fill As An Approach Bridge Fill On Sheet-Pile Structures," J. JalanJembatan, 37, no. 2, 87-101, 2020.

3. Ministry of PUPR, "Guidelines for Specifications of Lightweight Materials with Foam Mortar for Road Construction (Pedoman Spesifikasi Material Ringan Dengan Mortar Busa Untuk Konstruksi Jalan,)" 2015.

https://binamarga.pu.go.id/uploads/files/410/pedoma n-spesifikasi-material-ringan-dengan-mortar-busauntuk-konstruksi-jalan.pdf.

4. M. A. P. Adi, Y. Lastiasih, and I. B. Mochtar, "Alternative Planning for Road Filling with Sirtu Material and Lightweight Mortar Foam on BatangSemarang (Alternatif Perencanaan Timbunan Jalan dengan Material Sirtu dan Material Ringan Mortar Busa pada Jalan Tol Batang-Semarang) Seksi III 
Weleri-Kendal STA 414+ 525-STA 424+ 576," J. Transp. Sist. Mater. dan Infrastruktur, 1, no. 2, 7277, 2019.

5. E. F. Simbolon, "Use of Foam Agent in Making Concrete Brick (Penggunaan Foam Agent Dalam Pembuatan Bata Beton Ringan).” Medan: Universitas Sumatera Utara, 2015.

6. S. Sulaiman, "Water permeability and carbonation on foamed concrete." Universiti Tun Hussein Onn Malaysia, 2011.

7. H. T. Santoso, "Use of CSS-Mortar Foam as an Alternative for Selection of Flyover Construction Types on Construction Costs for Road and Bridge Construction (Penggunaan CSS-Mortar Busa Sebagai Alternatif Pemilihan Tipe Konstruksi Jalan Layang terhadap Biaya Konstruksi)," BENTANG J. Teor. dan Terap. Bid. Rekayasa Sipil, 8, no. 2, pp. 87-98, 2020.

8. A. Al-Shwaiter, H. Awang, and M. A. Khalaf, "The influence of superplasticiser on mechanical, transport and microstructure properties of foam concrete," J. King Saud Univ. Sci., 2021.

9. G. Calis, S. A. Yildizel, S. Erzin, and B. A. Tayeh, "Evaluation and optimisation of foam concrete containing ground calcium carbonate and glass fibre (experimental and modelling study)," Case Stud. Constr. Mater, 15, e00625, 2021.

10. E. Kuzielová, L. Pach, and M. Palou, "Effect of activated foaming agent on the foam concrete properties," Constr. Build. Mater., 125, 998-1004, 2016.

11. A. Mestnikov, S. Semenov, V. Strokova, and V. Nelubova, "Autoclave foam concrete: Structure and properties," in AIP Conference Proceedings, 2016, 1698, no. 1, 70010.

12. H. D. Foth, "Fundamentals of soil science," Soil Sci., 125, no. 4, 272, 1978.

13. ASTM, "Standard specification for flow table for use in tests of hydraulic cement," ASTM Int., 1-6, 2014.

14. Standar Nasional Indonesia, "Concrete Compression Test procedure with Cylindrical Test (Cara Uji kuat tekan beton dengan benda uji silinder)," 1974.

15. Badan Standarisasi Nasional, "Portland Cement Mortar Compressive Strength Test Method for Civil Works (Metode pengujian kekuatan tekan mortar semen Portland untuk pekerjaan sipil)," SNI 036825-2002, Indonesia, 2002. 